УДК 341.340 .134

DOI: 10.17277/voprosy.2015.03.pp.247-250

\title{
APPLICATION AND INTERPRETATION OF INTERNATIONAL LAW
}

\author{
I. S. Iskevich, E. A. Suchkova \\ Tambov State Technical University, Tambov \\ Reviewed by Doctor of Law, Professor V. G. Baev
}

Keywords: content; implementation of international norms; interpretation of international legal norms; legal norms; national law.

\begin{abstract}
The authors discuss the problems of application and interpretation of international legal norms. The emphasis is put on types and methods of interpretation. Special attention is paid to the synthesis of application of international and national legal norms.
\end{abstract}

The concept "application of law" has the general and specific meaning. On the one hand, it covers all legal ways of implementing the law, and on the other hand, it is considered as the implementation of the law in the case of offence or dispute on the rights.

The application of law to particular cases is as follows:

- establishing the factual circumstances;

- legal qualification of the factual circumstances, i.e. establishing whether they fall under the norms of the international law, and if so, what these norms are;

- the definition of the legal characteristics of the relevant norms, their scope, particularly in relation to these subjects;

- understanding the content of the legal norm, i.e. the full interpretation;

- choosing the method of application of legal norms to the factual circumstances;

- actions to ensure the implementation of the choice made.

Organizational principles of the international law application. There are international and national methods of application of international legal norms. The international method is implemented in the activities of states in the world arena, as well as in the activities of international bodies and organizations created in these states. The national method finds its expression in the internal activities of the state which are necessary for the implementation of international legal norms [1].

Искевич Ирина Сергеевна - кандидат юридических наук, доцент кафедры «Международное право», e-mail: Irina_77707@list.ru; Сучкова Екатерина Александровна - магистрант кафедры «Международное право», ТамбГТУ, г. Тамбов.

УНИВЕРСИТЕТ им. В.И. ВЕРНАДСКОГО. №3(57). 2015. 
The interpretation is a process of clarification of the content of norms, goals applicable for the specific situation, relations with other norms of the international law, and the legal characteristics.

Means of interpretation were determined by the Vienna Convention on the law of treaties in 1969, which divided them into primary and secondary. The primary means include the context of the treaty in the broad sense of the term. The secondary means of interpretation are related to the preparatory work and the circumstances of the treaty conclusion. The use of the secondary means is permitted only if the use of the primary means leaves the value of the norm obscure or leads to obviously absurd results [2].

Rules and methods of interpretation. The Vienna Convention sets forth the principle of good faith in the first place. The interpretation must be bona fide, i.e., honest, taking into account the interests of all parties concerned, and it must be aimed to identify the real content of norms.

The principle of interpretation unity requires the norm to be understood uniformly in all cases, for all subjects.

The principle of effectiveness requires that the results of interpretation lead to the achievement of the goals of the norm, making it effective.

The rule of special law requires the interpretation to recognize the advantage of the special norms in relation to the general norms, because they are directly related to the present case, specify the general norm, and sometimes make it an exception.

Ways of interpreting:

- grammatical, i.e. clarifying the meaning of the norm by analyzing the text from the point of etymology, vocabulary, syntax, and even the style of the language; logic;

- logical, i.e. analyzing the norms through the use of laws and rules of

- specially-legal, i.e. clarifying the legal characteristics of international legal norms. It comprises such questions as if the norm is in force, the range of subjects covered by its action, etc.;

- systematic, i.e. analyzing the norm as an element of the international law in its relation with the purposes and principles, as well as with other norms;

- teleological, i.e. defining the content of the norm in accordance with its goal;

- historical, i.e. clarifying the meaning of the norms according to the historical conditions of its adoption.

The scope of the international law is understood as the scope of the international legal means of influence on the object of regulation. This scope includes three main aspects - subject, object and spatial.

The subject scope is determined by the range of subjects covered by the international law. The object scope is the range of regulated relations, which is its object. The spatial (or territorial) scope of the international law attracts special attention of the practice. The treaty resolutions on the scope are usually dedicated to it. We are talking about land, water, air, space areas, where the international law works.

The differentiation of the spatial scope of the international and national law. The state has complete and exclusive sovereignty within its territory. 
The border of the state territory runs along the outer border of the territorial waters. However, the international law has restricted the implementation of the rights of the sovereign in the territorial waters in the interests of international shipping, providing foreign vessels the right of the innocent passage. The innocent passage is governed by the laws of the coastal state, but it must be consistent with the international law.

In order to be able to regulate the relations with participation of physical and legal entities, the rules in the international law shall enter into the legal system of the country in the established order. This process is usually called transformation. It can be common and individual. In the general transformation the state establishes that all or only certain types of the accepted international law are considered as a part of the national law of the country. In the individual transformation it is necessary in each case to introduce international norms in the law of the country by a special act.

A special kind of implementation of international norms is reference. Many laws state that certain provisions of the law will be applied in accordance with a particular treaty or that in particular cases it is necessary to apply a treaty.

The modern international law fully determines the content of the central provisions of the constitutional law - norms on human rights. The role of the international law in this is recognized in the constitutional law, which establishes that human rights are determined in accordance with international legal norms. Moreover, the process of establishing the democracy principle is in progress, according to which the only legitimate form of the state government is democracy. It is explained by the fact that otherwise it is impossible to secure a peaceful world order, and, consequently, the survival of mankind.

The influence of the international law is especially considerable on the agencies of foreign relations. So, the international law determines what agencies can give a final approval to the obligation of international contracts without special authorities.

The international law also influences on the legality of power. A legislator is limited to international obligations of the state. Moreover, it is obligatory to issue laws, which are necessary for the implementation of international legal norms.

Strengthening of the influence of the international law on the national one, including the constitutional law, causes new forms of controlling the congruence of international obligations to the constitution of the country. The substantial role herein can play constitutional courts which are becoming widespread. The main purpose of these courts is to watch after the constitutionality of legislative acts. The control of the constitutionality of international treaties is a new function for them. The courts are careful with this question [3].

Thus, the considered acts generate moral and political obligations only, and it does not eliminate their influence on the national law. In addition, studying the content of international legal norms, including those which are incorporated in the national law, it is necessary to resort to the help of resolutions of conferences and organizations. There are methods of giving legal force to the content of resolutions and in such a way including them into the national law. 


\section{References}

1. Бирюков, П. Н. Международное право : учеб. пособие / П. Н. Бирюков. М. : Юристь, 200. -416 с.

2. Лукашук, И. И. Толкование норм международного права / И. И. Лукашук, О. И. Лукашук. - M. : Nota Bene, 2002. - 160 c.

3. Международное право : учеб. для вузов / отв. ред.: Г. В. Игнатенко, О. И. Тиунов. - М. : НОРМА - ИНФРА-М, 1999. - 584 с.

\section{References}

1. Biryukov P.N. Mezhdunarodnoe pravo (International law), Moscow: Lawyer, 2000, $416 \mathrm{p}$.

2. Lukashuk I.I., Lukashuk O.I. Tolkovanie norm mezhdunarodnogo prava (The interpretation of international law), Moscow: Nota Bene, 2002, 160 p.

3. Ignatenko. G.I., Tiunov O.I. (Eds.) Mezhdunarodnoe pravo (International law), Moscow: NORMA - INFRA-M, 1999, 584 p.

\section{Применение и толкование норм международного права}

\section{И. С. Искевич, Е. А. Сучкова}

ФГБОУ ВПО «Тамбовский государственный технический университет», г. Тамбов

Ключевые слова: имплементация международных норм; национальное право; нормы права; содержание; толкование норм международного права;

Аннотация: Рассмотрены проблемы применения и толкования норм международного права. Раскрыты виды и способы толкования. Особое внимание уделено синтезу применения норм международного и национального законодательства.

(С) И. С. Искевич, Е. А. Сучкова, 2015 